\section{Tradução e adaptação transcultural do instrumento da Organização Mundial da Saúde sobre o uso de sinais de alarme para dengue por profissionais de saúde}

\author{
Translation and cross-cultural adaptation of the \\ World Health Organization staff questionnaire \\ on dengue warning signs for use in Brazil
}

\section{Traducción y adaptación cultural del instrumento de la Organización Mundial de la Salud para el uso de signos de alarma sobre dengue por parte de profesionales de la salud}

\author{
1 Instituto Nacional de \\ Infectologia Evandro Chagas, \\ Fundação Oswaldo Cruz, \\ Rio de Janeiro, Brasil. \\ 2 Escola Nacional de Saúde \\ Pública Sergio Arouca, \\ Fundação Oswaldo Cruz, \\ Rio de Janeiro, Brasil. \\ Correspondência \\ Y. H. M. Hökerberg \\ Instituto Nacional de \\ Infectologia Evandro Chagas, \\ Fundação Oswaldo Cruz. \\ Av. Brasil 4365, Rio de \\ Janeiro, RJ 21045-900, Brasil. \\ yarahahr@gmail.com
}

\begin{abstract}
Early recognition of warning signs and treatment of severe dengue cases is the main strategy for reducing case-fatality, especially in children, who usually present few symptoms and can progress rapidly to dengue shock syndrome. The objective of this study was to elaborate the Brazilian version of the World Health Organization (WHO) staff questionnaire on the use and value of dengue warning signs, through translation and back-translation of the WHO questionnaire, followed by an expert panel consensus, pretest $(n=13)$, and pilot study $(n=20)$ of the preliminary version. Comparison of the original questionnaire in English and the back-translation showed that 8 of the 49 items had been extensively or completely altered, and three were rephrased. The expert panel added the warning signs listed by the Brazilian Ministry of Health. In the final version of the questionnaire, the item "ranking of warning signs" was rephrased and the answer option "do not know" was excluded. The Brazilian version of the WHO staff questionnaire allows assessing health professionals' experience and perceptions regarding the use of warning signs included in the recent dengue guidelines.
\end{abstract}

Dengue; Questionnaires; Health Personnel
Luana Sicuro Correa 1

Yara Hahr Marques Hökerberg 1 Regina Paiva Daumas 2 Patrícia Brasil 1

\section{Resumo}

A identificação precoce de sinais de alarme e o tratamento de dengue grave são as principais estratégias para reduzir a letalidade da doença, principalmente em crianças, usualmente oligosintomáticas e com rápida progressão para o choque. O objetivo foi elaborar a versão brasileira do instrumento proposto pela Organização Mundial da Saúde (OMS) para avaliar o uso de sinais de alarme para dengue grave. Tradução e retrotradução do instrumento original em inglês, seguidas de um painel de especialistas, préteste $(n=13)$ e estudo piloto $(n=20)$ da versão preliminar. A comparação do instrumento original com a retrotradução mostrou que apenas 8 de 49 itens foram julgados como muito ou completamente alterados, três dos quais foram revistos. O painel de especialistas incluiu os sinais preconizados pelo Ministério da Saúde do Brasil. Na versão final do questionário, o item "classificação dos sinais de alarme" foi reformulado e a opção de resposta "não sei" foi excluída. A versão brasileira do instrumento da OMS permite avaliar o uso dos sinais de alarme, preconizados nos recentes manuais de dengue.

Dengue; Questionários; Pessoal de Saúde 
A identificação de sinais preditores de gravidade em dengue é uma das principais estratégias para reduzir a letalidade, particularmente em crianças, faixa etária em que a apresentação clínica é comumente inespecífica e com rápida evolução para o choque 1 .

Em 2009, com base no estudo multicêntrico Dengue Control Study (DENCO) 2, a Organização Mundial da Saúde (OMS) propôs uma nova classificação para dengue, que valoriza os sinais clínico-laboratoriais preditores de gravidade sinais de alarme ${ }^{3}$. O estudo de Barniol et al. ${ }^{4}$ serviu de base para a elaboração de instrumento que verifica o uso e a importância atribuída a cada sinal de alarme. Entretanto, apenas um estudo avaliou o conhecimento, mas não o uso dos sinais de alarme da OMS 5 .

Desde 2002, o Brasil adota um protocolo para abordagem clínica do dengue que recomenda a identificação precoce de "sinais de alerta" 6 . Em 2011 7, o conjunto de sinais era mais abrangente do que o da OMS 3.

O objetivo deste trabalho foi elaborar a versão brasileira do instrumento da OMS sobre o uso de sinais de alarme para dengue a fim de aplicá-lo aos profissionais de saúde.

\section{Métodos}

O modelo adotado para adaptação transcultural seguiu a abordagem universalista 8,9 , que propõe a apreciação de seis equivalências: conceitual, de itens, semântica, operacional, de mensuração e funcional. Este estudo, realizado em 2011, restringiu-se à avaliação das quatro primeiras.

\section{O instrumento}

A Figura 1 apresenta o instrumento original. Possui duas seções: I. Características do respondente: idade, sexo, nível de atenção de atuação e ocupação; II. Atenção à dengue: experiência no atendimento em dengue, situação de encaminhamento, uso geral (sim/não) e de cada sinal de alarme. O item "ranking dos sinais" solicita que os sinais sejam classificados por ordem de importância. Finalmente, duas questões não estruturadas foram postuladas para os respondentes informarem os sinais que adicionariam ou retirariam da lista.

Três etapas foram realizadas: equivalências conceitual e de itens, semântica e operacional.

\section{Equivalência conceitual e de itens}

Foi feita uma revisão bibliográfica sobre dengue e contactado um membro do comitê de dengue da OMS para conhecer o processo de elaboração do instrumento-fonte. Três médicos, um pediatra, um infectologista e um epidemiologista avaliaram a pertinência dos sinais de alarme e dos demais itens do questionário no contexto brasileiro.

\section{Equivalência semântica}

Dois médicos (um tradutor) realizaram duas traduções independentes do instrumento do inglês para o português do Brasil. Quatro médicos distintos avaliaram a clareza semântica dos itens e termos médicos e elaboraram uma síntese, retrotraduzida para o inglês de forma independente por dois tradutores cegos para o original. Um avaliador externo, médico e tradutor com inglês fluente comparou o original $(\mathrm{O})$ com as duas retrotraduções (RT), cujos resultados foram registrados em planilha que dispunha os itens $\mathrm{O}$, RT1 e RT2 de forma aleatória e mascarada, com quatro opções de respostas: inalterado, pouco alterado, muito alterado ou completamente alterado. Se alterado, o avaliador indicava a versão a revisar com as observações.

\section{Equivalência operacional}

O formato e o modo de aplicação do questionário foram discutidos no consenso de especialistas e avaliado no pré-teste e estudo piloto.

\section{- Consenso de especialistas}

Oito especialistas bilíngues (dois pediatras, dois epidemiologistas, um infectologista, um médico de saúde da família e duas enfermeiras, uma das quais trabalhou anteriormente como técnica de enfermagem) e com experiência em dengue participaram de uma reunião de consenso para avaliar a pertinência, adequação e clareza dos itens e das opções de resposta, além da equivalência operacional. Previamente à reunião, eles receberam o resumo do projeto, a lista de sinais de alarme (OMS 3 e Ministério da Saúde 7), a síntese da tradução do instrumento e um roteiro semiestruturado para análise desta versão brasileira preliminar.

\section{- Pré-teste e estudo piloto}

A versão obtida no consenso foi aplicada a 13 profissionais: 5 médicos, 5 enfermeiros e 3 técnicos de enfermagem, todos envolvidos no atendimento de dengue em crianças. O questionário era acompanhado de cinco perguntas abertas sobre a compreensão e aceitação do formato, pertinência dos itens e das opções de respostas. Os 
Figura 1

Staff Questionnaire for Qualitative/Semi-quantitative Warning Sign Study.

I. Introduction: A revised dengue case classification and updated clinical guidelines have been introduced. We would like to get your views about how the use and value of warning signs.

II. Questions:

Section 1 - Characteristics of the respondent

1. Age of respondent:_ (How many years are you old?)

3. At which level of health care system do you mainly work? (Circle the one most appropriate)

2. Sex: Male $\square$ Female $\square$

A: Primary care (health post/ health centre)

B: Secondary care (hospital, no intensive care unit)

$\mathrm{C}$ : Tertiary care (university/ teaching hospital/ with intensive care unit)

4. What is your primary job title within the healthcare system? (Circle the one most appropriate)

A: General medicine physician B: Paediatrician

D: Other specialist physician ___ (write in type of specialist)

G: Pediatric nurse H: Other nurse (write in type of nurse)

$\mathrm{K}$ : Epidemiologist/ statistician

Section 2 - Dengue care in your current position

5 . Do you have experiences in the management of dengue patients?

Section 2 - Dengue care in your current position

6. How long have you been working with dengue patients?

7. How many patients with suspected dengue did you care for within the last year?

9. When do you refer a patient suspected of dengue to a higher level of care? (Please cross first the type of referral as this depends on the level of health care where you work)

C: Internal medicine

E: General nurse F: Infectious disease nurse

I: Laboratory technician J: Medical Director

L: Intern/resident/social service year

(Hospital staff go to Question 11 a after completing this one)

Yes $\square$ No $\square$ (If NO, stop here)

I refer the patient..

A. If he or she has fever and rash

B. If he or she has persistent vomiting

C. If he or she has cold, clammy extremities

D. If he or she has bleeding from nose or gums

E. Any infant suspected of dengue

F. If he or she has profound thrombocytopenia

G. If he or she has severe abdominal pain

H. No predetermined criteria/ based on clinician's judgment

I. Other

10a. Are warning signs used if you want to refer a patient to the hospital? (for health centre staff only)

$10 \mathrm{~b}$. Which of the following warnings signs do you use?

A. Severe/continuous Abdominal pain or tenderness

B. Abdominal tenderness

C. Persistent vomiting

D. Clinical fluid accumulation

E. Mucosal bleeding

F. Lethargy/ restlessness

G. Liver enlargement $>2 \mathrm{~cm}$

A: less than 1 year $\quad$ B: one to five years

C: more than 5 years
A: None
B: $1-50$
$\mathrm{C}:>50$

$\square$ Referral from primary care (Health Center) to hospital

$\square$ Referral from general ward to intensive care unit(within hospital)

$\square$ Referral from hospital to higher level teaching hospital

H. Laboratory: increase in HCT concurrent with rapid decrease in platelet count

11a. Are warning signs being used in your facility?

(for hospital staff only)

Yes $\square$ No $\square$ Don't know $\square$ Not applicable $\square$

Yes $\square$ No $\square$ Don't know $\square$ Not applicable $\square$

Yes $\square$ No $\square$ Don't know $\square$ Not applicable $\square$

Yes $\square$ No $\square$ Don't know $\square$ Not applicable $\square$

Yes $\square$ No $\square$ Don't know $\square$ Not applicable $\square$

Yes $\square$ No $\square$ Don't know $\square$ Not applicable $\square$

Yes $\square$ No $\square$ Don't know $\square$ Not applicable $\square$

Yes $\square$ No $\square$ Don't know $\square$ Not applicable $\square$

$11 \mathrm{~b}$. Which of the following warnings signs do you routinely use in

your facility? (Please complete all lines)

Yes $\square$ No $\square$ Don't know $\square$

(Please complete all lines and go to Question 12)

Yes $\square$ No $\square$ Don't know $\square$

Yes $\square$ No $\square$ Don't know $\square$

Yes $\square$ No $\square$ Don't know $\square$

Yes $\square$ No $\square$ Don't know $\square$

Yes $\square$ No $\square$ Don't know $\square$

Yes $\square$ No $\square$ Don't know $\square$

Yes $\square$ No $\square$ Don't know $\square$

Yes $\square$ No $\square$ Don't know $\square$

Yes $\square$ No $\square$ Don't know $\square$ 


\begin{tabular}{|l|l|}
\hline $\begin{array}{l}\text { 11b. Which of the following warnings signs do you routinely use in } \\
\text { your facility? (Please complete all lines) }\end{array}$ & \\
\hline A. Severe/continuous Abdominal pain or tenderness & Yes $\square$ No $\square$ Don't know $\square$ \\
\hline B. Abdominal tenderness & Yes $\square$ No $\square$ Don't know $\square$ \\
\hline C. Persistent vomiting & Yes $\square$ No $\square$ Don't know $\square$ \\
\hline D. Clinical fluid accumulation & Yes $\square$ No $\square$ Don't know $\square$ \\
\hline E. Mucosal bleeding & Yes $\square$ No $\square$ Don't know $\square$ \\
\hline F. Lethargy/ restlessness & Yes $\square$ No $\square$ Don't know $\square$ \\
\hline G. Liver enlargement > 2cm & Yes $\square$ No $\square$ Don't know $\square$ \\
\hline $\begin{array}{l}\text { H. Laboratory: increase in HCT concurrent with rapid decrease in } \\
\text { platelet count }\end{array}$ & Yes $\square$ No $\square$ Don't know $\square$ \\
\hline $\begin{array}{l}\text { 12. Please list the warning signs in the list below according to your } \\
\text { order of importance to help detecting dengue. }\end{array}$ & $\begin{array}{l}\text { Give score of 1 to } 7 \text { (1 being the most important in your } \\
\text { opinion) }\end{array}$ \\
\hline A. Abdominal pain or tenderness & \\
\hline B. Persistent vomiting & \\
\hline C. Clinical fluid accumulation & \\
\hline D. Mucosal bleeding & \\
\hline E. Lethargy/ restlessness & \\
\hline F. Liver enlargement $>$ 2cm & \\
\hline G. Laboratory: increase in HCT concurrent with rapid decrease in \\
\hline$\quad$ platelet count & \\
\hline 13. What warning signs would you add to the above list? & $\square$ \\
\hline 14. What warning signs would you cross from the above list? & \\
\hline
\end{tabular}

ajustes no instrumento decorrentes desta etapa foram avaliados no estudo piloto, com vinte profissionais do serviço de pediatria de um hospital universitário.

O estudo foi aprovado por dois Comitês de Ética: do Instituto de Pesquisa Clínica Evandro Chagas, Fundação Oswaldo Cruz (CAAE no 0032.0.009.000-11) e do Hospital Universitário Pedro Ernesto (CAAE no 0238.0.228.009-11).

\section{Resultados}

\section{Equivalência conceitual e de itens}

A revisão dos manuais nacionais e internacionais de dengue e a discussão entre os especialistas concluíram pela pertinência dos itens. Entretanto, os especialistas consideraram acrescentar os sinais listados pelo Ministério da Saúde em 2011.

\section{Equivalência semântica}

A comparação entre o instrumento original e as duas retrotraduções mostrou que o significado referencial da maioria dos itens ou categorias de resposta foi avaliado como inalterado. A Tabela 1 mostra os itens considerados alterados. Apenas a vinheta introdutória do questionário foi considerada completamente alterada. As perguntas "experiência em dengue" e "uso de sinais de alarme" e os sinais "extremidades frias e úmidas", "dor abdominal", "dor à palpação abdominal” e "alteração laboratorial” foram considerados muito alterados.

\section{Equivalência operacional}

Os especialistas consideraram a versão brasileira adequada, mas sugeriram substituir termos médicos por expressões mais coloquiais (e. g. queda de plaquetas ao invés de trombocitopenia), além de incluir os sinais de alarme preconizados pelo Ministério da Saúde 7: hemorragias importantes (hematêmese ou melena), hipotensão postura ou lipotímia, diminuição da diurese, diminuição repentina da temperatura corporal/hipotermia, desconforto respiratório e hepatomegalia dolorosa. Também, sugeriram incluir exemplos nas opções de resposta do item "nível de atenção de atuação". Houve divergências quanto à pertinência da opção de resposta "não sei" nos itens sobre uso de sinais de alarme.

Todos os especialistas julgaram o item "ranking dos sinais" pouco claro, pois o critério de importância pode ser definido pela gravidade 
Itens considerados alterados na comparação entre o original em inglês e as retrotraduções do instrumento da Organização Mundial da Saúde (OMS).

\begin{tabular}{|c|c|c|c|c|}
\hline Original & Retrotradução 1 & $\begin{array}{l}\text { Significado } \\
\text { referencial }\end{array}$ & Retrotradução 2 & $\begin{array}{l}\text { Significado } \\
\text { referencial }\end{array}$ \\
\hline $\begin{array}{l}\text { I. Introduction: A revised dengue } \\
\text { case classification and updated } \\
\text { clinical guidelines have been } \\
\text { introduced. We would like to get } \\
\text { your views about how the use } \\
\text { and value of warning signs. }\end{array}$ & $\begin{array}{l}\text { The revised classification of dengue } \\
\text { cases and the updated clinical guidelines } \\
\text { have been introduced. We want to know } \\
\text { your opinion on the use and importance } \\
\text { of warning signs in clinical practice. }\end{array}$ & CA & $\begin{array}{l}\text { The reviewed classification of dengue } \\
\text { cases and updated clinical guidelines } \\
\text { were introduced. We would like to get } \\
\text { your opinion on the use and importance } \\
\text { of the warning signs in clinical practice. }\end{array}$ & CA \\
\hline $\begin{array}{l}\text { Section } 2 \text { - Dengue care in your } \\
\text { current position. } \\
5 \text {. Do you have experiences in } \\
\text { the management of dengue } \\
\text { patients? } \square \text { Yes } \square \text { No }\end{array}$ & $\begin{array}{l}\text { Section } 2 \text { - Experience in dengue } \\
\text { management } \\
\text { 5. Do you have any experience in clinical } \\
\text { management of dengue patients? } \\
\square \text { Yes } \square \text { No }\end{array}$ & PA & $\begin{array}{c}\text { Section } 2 \text { - Experience in dengue care } \\
\text { 5. Do you have experience in clinical } \\
\text { management of dengue patients? } \\
\square \text { Yes } \square \text { No }\end{array}$ & PA \\
\hline $\begin{array}{l}\text { 6. How long have you been } \\
\text { working with dengue patients? } \\
\text { A: less than } 1 \text { year } \\
\text { B: one to five years } \\
\text { C: more than } 5 \text { years }\end{array}$ & $\begin{array}{l}\text { How long have you worked with dengue } \\
\text { patient care? } \\
\text { A: less than } 1 \text { year } \\
\text { B: } 1 \text { to } 5 \text { years } \\
\text { C: more than } 5 \text { years }\end{array}$ & MA & $\begin{array}{l}\text { How long you do work in dengue } \\
\text { patient's care? } \\
\text { A: Less than } 1 \text { year } \\
\text { B: from } 1 \text { to } 5 \text { years } \\
\text { C: more than } 5 \text { years }\end{array}$ & MA \\
\hline $\begin{array}{l}\text { 7. How many patients with } \\
\text { suspected dengue did you care } \\
\text { for within the last year? }\end{array}$ & $\begin{array}{l}\text { How many patients with suspicion of } \\
\text { dengue did you treat in the last year? }\end{array}$ & IN & $\begin{array}{c}\text { How many patients with suspected } \\
\text { dengue did you attend during the last } \\
\text { year? }\end{array}$ & IN \\
\hline $\begin{array}{l}\text { 9. When do you refer a patient } \\
\text { suspected of dengue to a higher } \\
\text { level of care? (Please cross } \\
\text { first the type of referral as this } \\
\text { depends on the level of health } \\
\text { care where you work) }\end{array}$ & $\begin{array}{c}\text { In what type of situation do you refer a } \\
\text { patient with dengue to a health unit with } \\
\text { a higher level of complexity? (Please } \\
\text { check the most appropriate choice, since } \\
\text { this depends on the level of complexity } \\
\text { of the health unit where you mainly } \\
\text { work) }\end{array}$ & & $\begin{array}{l}\text { In which situation you refer a patient } \\
\text { with dengue to a health unit with a } \\
\text { higher level of complexity? (Please mark } \\
\text { the most appropriate option, as this } \\
\text { depends on the level of complexity of } \\
\text { the health unit in which you operate } \\
\text { primarily). }\end{array}$ & \\
\hline $\begin{array}{l}\square \text { Referral from primary care } \\
\text { (Health Center) to hospital }\end{array}$ & $\begin{array}{c}\square \text { from the primary care unit (Health } \\
\text { Center, Health Post, Family Health Unit) } \\
\text { to the hospital }\end{array}$ & IN & $\begin{array}{c}\square \text { from primary care unit (Health Center, } \\
\text { Health Care Unit, Family Health Unit) to } \\
\text { the hospital }\end{array}$ & IN \\
\hline $\begin{array}{l}\square \text { Referral from general ward } \\
\text { to intensive care unit(within } \\
\text { hospital) }\end{array}$ & $\begin{array}{c}\square \text { from the ward to the intensive care } \\
\text { unit (inside the same hospital) }\end{array}$ & & $\begin{array}{l}\square \text { from ward to the intensive care unit } \\
\text { (within the hospital) }\end{array}$ & \\
\hline $\begin{array}{l}\square \text { Referral from hospital to higher } \\
\text { level teaching hospital }\end{array}$ & $\begin{array}{c}\square \text { from the general hospital to a referral } \\
\text { hospital }\end{array}$ & & $\begin{array}{l}\square \text { from the General Hospital to a } \\
\text { reference hospital }\end{array}$ & \\
\hline I refer the patient ... & I refer the patient when he/she. & & I refer the patient when... & \\
\hline $\begin{array}{l}\text { C. If he or she has cold, clammy } \\
\text { extremities }\end{array}$ & Has cold and moist extremities & IN & Has cold and wet extremities & PA \\
\hline $\begin{array}{l}\text { 10a. Are warning signs used if } \\
\text { you want to refer a patient to } \\
\text { the hospital? (for health centre } \\
\text { staff only) }\end{array}$ & $\begin{array}{c}\text { Do you use the World Health } \\
\text { Organization (or Ministry of Health) } \\
\text { warning signs to refer a patient to } \\
\text { the hospital? (to be answered only by } \\
\text { workers in primary care units) }\end{array}$ & PA & $\begin{array}{l}\text { Do you use the warning signs of the } \\
\text { World Health Organization (or the } \\
\text { Ministry of Health) to refer a patient to } \\
\text { the hospital? (To be answered only by } \\
\text { workers of primary care units) }\end{array}$ & PA \\
\hline
\end{tabular}

(continua)

ou pela frequência de ocorrência, além da dificuldade de avaliar o papel de cada sinal isoladamente. Ainda assim, houve consenso quanto à manutenção desse item após reformulação do enunciado, e quanto à inclusão de dois novos itens para justificar o critério de importância, um estruturado e outro não estruturado. Para evitar dados faltantes, decidiu-se pela autoadministração de instrumento anônimo sob supervisão. 
Tabela 1 (continuação)

\begin{tabular}{|c|c|c|c|c|}
\hline Original & Retrotradução 1 & $\begin{array}{l}\text { Significado } \\
\text { referencial }\end{array}$ & Retrotradução 2 & $\begin{array}{l}\text { Significado } \\
\text { referencial }\end{array}$ \\
\hline $\begin{array}{l}10 \mathrm{~b} . \text { Which of the following } \\
\text { warnings signs do you use? }\end{array}$ & $\begin{array}{l}\text { Which of the following warning signs do } \\
\text { you use? }\end{array}$ & IN & $\begin{array}{l}\text { Which one (s) of the following warning } \\
\text { signs do you use? }\end{array}$ & IN \\
\hline $\begin{array}{l}\text { A. Severe/continuous abdominal } \\
\text { pain or tenderness }\end{array}$ & Strong and continuous abdominal pain & PA & Severe and continuous abdominal pain & IN \\
\hline B. Abdominal tenderness & Pain on abdominal palpation & PA & Pain on abdominal palpation & PA \\
\hline D. Clinical fluid accumulation & Serous effusion & MA & Serous effusion & MA \\
\hline $\begin{array}{l}\text { H. Laboratory: increase in } \mathrm{HCT} \\
\text { concurrent with rapid decrease in } \\
\text { platelet count }\end{array}$ & $\begin{array}{l}\text { Laboratory results: increased hematocrit } \\
\text { together with rapid fall in platelet count }\end{array}$ & IN & $\begin{array}{l}\text { Lab: increased hematocrit concomitant } \\
\text { to rapid decrease in platelet count }\end{array}$ & MA \\
\hline $\begin{array}{l}11 \mathrm{~b} . \text { Which of the following } \\
\text { warnings signs do you routinely } \\
\text { use in your facility? * }\end{array}$ & $\begin{array}{c}\text { Which of the following warning signs } \\
\text { do you routinely use in the health unit } \\
\text { where you work? }\end{array}$ & IN & $\begin{array}{c}\text { Which one(s) of the following warning } \\
\text { signs do you routinely use in the health } \\
\text { facility you work? }\end{array}$ & IN \\
\hline $\begin{array}{l}\text { A. Severe/continuous abdominal } \\
\text { pain or tenderness }\end{array}$ & Strong and continuous abdominal pain & PA & Severe and continuous abdominal pain & IN \\
\hline B. Abdominal tenderness & Pain on abdominal palpation & PA & Pain on abdominal palpation & PA \\
\hline $\begin{array}{l}\text { 12. Please list the warning signs } \\
\text { in the list below according to } \\
\text { your order of importance to } \\
\text { help detecting dengue. Give } \\
\text { score of } 1 \text { to } 7 \text { ( } 1 \text { being the most } \\
\text { important in your opinion) ** }\end{array}$ & $\begin{array}{c}\text { Please number the warning signs } \\
\text { listed below according to the order } \\
\text { of importance for assisting in dengue } \\
\text { management. Use a score from } 1 \text { to } 7 \\
\text { (with } 1 \text { being the most important in your } \\
\text { opinion) }\end{array}$ & IN & $\begin{array}{l}\text { Please number the warning signs } \\
\text { listed below according to the order of } \\
\text { importance to assist in the management } \\
\text { of dengue. Use the score 1-7 (1 being } \\
\text { the most important in your opinion) }\end{array}$ & IN \\
\hline A. Abdominal pain or tenderness & $\begin{array}{l}\text { Strong and continuous abdominal pain } \\
\text { or pain on abdominal palpation }\end{array}$ & PA & Severe and continuous abdominal pain & PA \\
\hline $\begin{array}{l}\text { 13. What warning signs would } \\
\text { you add to the above list? }\end{array}$ & $\begin{array}{c}\text { What warning signs would you add to } \\
\text { the above-mentioned list? }\end{array}$ & IN & $\begin{array}{c}\text { Which one(s) of the warning sign(s) } \\
\text { would you add to the above mentioned } \\
\text { list? }\end{array}$ & MA \\
\hline $\begin{array}{l}\text { 14. What warning signs would } \\
\text { you cross from the above list? }\end{array}$ & $\begin{array}{l}\text { Which warning signs would you remove } \\
\text { from the above-mentioned list? }\end{array}$ & MA & $\begin{array}{c}\text { Which one(s) of the warning sign(s) } \\
\text { would you withdraw from the above } \\
\text { mentioned list? }\end{array}$ & MA \\
\hline
\end{tabular}

CA: completamente alterado; IN: inalterado; MA: muito alterado; PA: pouco alterado.

* Os sinais C-H são os mesmos de 10b;

** Os sinais B-G equivalem aos listados como C-H em $10 \mathrm{~b}$.

No pré-teste, todos os 13 participantes consideraram o instrumento de fácil compreensão, à exceção do item “ranking dos sinais”. Quatro respondentes tiveram dificuldade de compreender o item "critério utilizado para encaminhamento" - "Em que situação você encaminha um paciente COM DENGUE (ou suspeita de dengue) a uma unidade de saúde com maior nível de complexidade?" -, posteriormente reformulado; e dois sugeriram a retirada da opção de resposta "não sei" dos itens sobre o uso de cada sinal de alarme, o que foi acatado. Apenas um participante relatou desconforto no preenchimento por "medo de errar", o que serviu de exemplo no treinamento de aplicadores para abordagem dos participantes, enfatizando-se o caráter não avaliativo da pesquisa devido à falta de evidências consistentes quanto aos sinais de alarme para dengue grave, particularmente em crianças. O preenchimento variou de 15 a 20 minutos.

No estudo piloto, dos vinte participantes (tempo máximo = 15 minutos), apenas um teve dificuldade com os enunciados dos itens. A Figura 2 apresenta a versão brasileira do instrumento.

\section{Discussão}

A versão brasileira do instrumento da OMS mostrou-se pertinente por permitir uma análise da frequência de uso de cada sinal de alarme para dengue. Essa versão mostrou-se de fácil preenchimento e compreensão, à exceção do item "ranking dos sinais".

Este parece ser o único instrumento que visa avaliar o uso dos sinais de alarme para dengue 
Figura 2

Versão brasileira do instrumento

Recentemente, uma classificação revisada de caso de dengue e diretrizes clínicas atualizadas foram propostas pela Organização Mundial da Saúde. O objetivo deste estudo é identificar se os sinais de alarme utilizados na prática pelos profissionais são os mesmos que (ou estão de acordo com) aqueles definidos pela Organização Mundial da Saúde e pelo Ministério da Saúde. Para isso, gostaríamos de obter sua opinião sobre a utilização e a importância dos sinais de alarme na prática clínica.

A. CARACTERÍSTICAS DO PARTICIPANTE

A1. Qual é a sua data de nascimento?

A2. Qual é o seu sexo? 1.Masculino 2.Feminino

A3. Em que nível de atenção do sistema de saúde você trabalha?

1. Atenção primária (Unidade de atenção primária, Centro ou Posto de Saúde ou Programa de Saúde da Família)

3. Atenção terciária (Hospital com leitos para internação, Hospital de referência, Hospital universitário ou Hospital de ensino) Se SIM, o hospital possui Unidade de Tratamento Intensivo (UTI)? Sim/Não

A4. Qual é a sua ocupação principal no serviço ou sistema de saúde? Marque apenas um item, o mais adequado à sua ocupação principal

3. Outra especialidade Médica:_ (nome da 4. Enfermeiro especialidade)

5. Enfermeiro de doenças infecciosas 6. Enfermeiro pediátrico

8. Outro tipo de Enfermeiro (especificar)

Marque apenas um item, o mais adequado a sua atividade principal

10. Epidemiologista ou Estatístico

2. Atenção secundária (Unidade de pronto atendimento com leito para observação ou curta permanência UPA, Policlínica ou Unidade de atendimento ambulatorial especializado)

1. Médico de Família 2. Médico Pediatra

B. EXPERIÊNCIA NO ATENDIMENTO AO DENGUE

B5. Você tem experiência no manejo clínico de pacientes com dengue?

B6. Há quanto tempo você trabalha no atendimento de pacientes com dengue?

7. Técnico de enfermagem

9. Diretor médico

11. Interno ou Estagiário ou Residente

B7. Quantos pacientes com suspeita de dengue você atendeu no último ano?

1. Sim

2. Não. Se NÃO, pare aqui!

1. Menos de 1 ano

2. 1 a 5 anos

3. Mais de 5 anos

1. Nenhum

2. 1 a 50 pacientes

3. Mais de 50 pacientes

B9. Em que situação você encaminha um paciente COM DENGUE (ou suspeita de dengue) a uma unidade de saúde com maior nível de complexidade?

1. da Unidade de atenção primária (Centro ou Posto de Saúde 2. da Enfermaria para a UTI (dentro do mesmo hospital) ou Unidade/Programa de Saúde da Família) para o hospital

3. de UPA ou Policlínicas para um hospital de referência

Eu encaminho o(a) paciente quando... Por favor, complete Se você trabalha em HOSPITAL, PULE PARA todas as linhas

A. Apresenta febre e exantema

QUESTÃO B11a

B. Apresenta vômitos persistentes

Sim $\square$ Não $\square$ Não se aplica $\square$

C. Está com as extremidades frias e úmidas

Sim $\square$ Não $\square$ Não se aplica $\square$

D. Apresenta sangramento pelo nariz ou gengivas

Sim $\square$ Não $\square$ Não se aplica $\square$

E. Qualquer lactente com suspeita de dengue

Sim $\square$ Não $\square$ Não se aplica $\square$

F. Tem menos de 100.000 plaquetas

Sim $\square$ Não $\square$ Não se aplica $\square$

G. Apresenta fortes dores abdominais

Sim $\square$ Não $\square$ Não se aplica $\square$

H. Nenhum critério predeterminado/com base na avaliação Sim $\square$ Não $\square$ Não se aplica $\square$ clínica

I. Outros motivos (especificar)

B10a. Você utiliza os sinais de alarme para DENGUE GRAVE

da Organização Mundial de Saúde (ou do Ministério da Saúde)

para encaminhar um paciente ao hospital? 
Figura 2 (continuação)

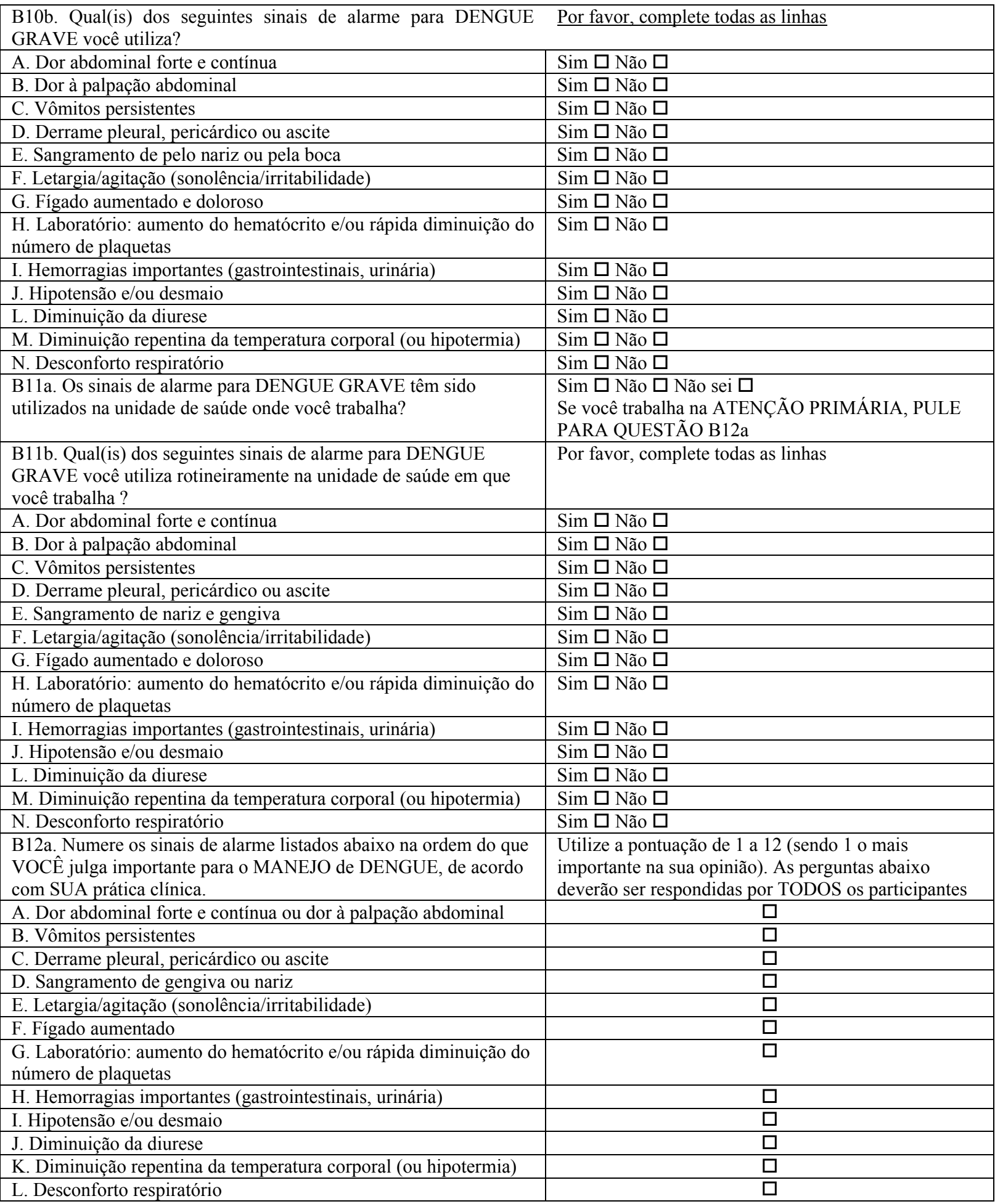




\begin{tabular}{|l|l|}
\hline B12b. Justifique a escolha do sinal mais importante: & \\
\hline $\begin{array}{l}\text { B12c. Qual critério de importância que você utilizou para ordenar } \\
\text { os sinais acima: }\end{array}$ & $\begin{array}{l}\text { 1. Maior utilidade na prática clínica. } \\
\text { 2. Maior gravidade. } \\
\text { 3. Outro critério. Qual? }\end{array}$ \\
\hline $\begin{array}{l}\text { B13. Qual(is) sinal(is) de alarme você ADICIONARIA à lista } \\
\text { acima citada? }\end{array}$ & \\
\hline $\begin{array}{l}\text { B14. Qual(is) sinal(is) de alarme você RETIRARIA da lista acima } \\
\text { citada? }\end{array}$ & \\
\hline
\end{tabular}

grave. Os instrumentos capturados nas publicações indexadas no PubMed visavam avaliar o conhecimento sobre dengue em leigos 10,11,12 ou de profissionais de saúde 13 , e o uso das diretrizes clínicas da OMS para a abordagem dos casos 4 . A comparação entre o original e a retrotradução mostrou que a maioria dos itens estava inalterada ou pouco alterada, demonstrando equivalência semântica. Entretanto, optou-se pela inclusão dos cinco sinais de alarme do Ministério da Saúde 7, por ser o órgão que normatiza os protocolos de atendimento do Sistema Único de Saúde (SUS), e de dois itens para esclarecer o critério adotado no item "ranking dos sinais". Nenhum item originalmente proposto foi retirado para preservar a comparabilidade.

Este estudo avaliou três equivalências recomendadas para a adaptação transcultural de instrumentos 8,9 , sendo ainda necessário avaliar a confiabilidade e testar a hipótese de que o conhecimento varia segundo as especificidades das ocupações em saúde. A versão brasileira do instrumento da OMS pode ser útil em futuras avaliações por considerar os diferentes níveis de atenção ao dengue.

\section{Resumen}

La detección precoz de los signos de alarma y el tratamiento de los casos graves de dengue constituyen la principal estrategia para reducir la letalidad, especialmente en niños, comúnmente oligosintomáticos y con rápida progresión hacia choques clínicos. El objetivo fue elaborar la versión brasileña del cuestionario de la Organización Mundial de la Salud (OMS), con el fin de evaluar el uso de los signos de alarma de dengue grave. Se realizó una traducción y retrotraducción del cuestionario en inglés, revisión por un panel de expertos, preprueba $(n=13)$ y un estudio piloto $(n=20)$ de la versión preliminar. La comparación del original con la retro- traducción mostró que 8 de los 49 ítems fueron considerados muy o completamente modificados, tres de los cuales fueron revisados. El panel de expertos incluyó los signos de alarma del Ministerio de Salud de Brasil. En la versión final, el item "ranking de los signos de alarma" fue revisado y se suprimió la opción de respuesta "no lo sé". La versión brasileña del cuestionario de la OMS permite evaluar el uso de los signos de alarma, recomendado en los actuales manuales sobre el dengue.

Dengue; Cuestionarios; Personal de Salud 


\section{Colaboradores}

L. S. Correa, Y. H. M. Hökerberg participaram da concepção, desenho, planejamento e coordenação do estudo, coleta, análise e interpretação dos resultados, redação e aprovação da versão final. R. P. Daumas colaborou no planejamento do estudo, discussão e revisão crítica do conteúdo e aprovação da versão final. P. Brasil contribuiu na concepção do estudo, discussão e revisão crítica do conteúdo e aprovação da versão final.

\section{Agradecimentos}

As autoras agradecem ao Dr. Axel Kroeger (OMS) pela disponibilidade, sugestões e esclarecimentos sobre o processo de elaboração do instrumento original; ao Dr Alfredo de Oliveira Neto (Faculdade de Ciências Médicas, Universidade do Estado do Rio de Janeiro); à Dra. Sheila Pone (Instituto Fernandes Figueiras, Fundação Oswaldo Cruz - IFF/Fiocruz); às Dras. Ana Cristina Ferreira, Maria Martins e Monica Costa (Instituto de Pesquisa Clínica Evandro Chagas, Fundação Oswaldo Cruz - IPEC/Fiocruz), pela valiosa contribuição na avaliação do questionário e pela disponibilidade em participar da reunião de consenso. L. S. Correa recebeu bolsa de Mestrado Fiocruz (2011-2012). Y. H. M. Hökerberg recebe auxílio da FAPERJ e P. Brasil, do CNPq.

\section{Referências}

1. Balasubramanian S, Ramachandran B, Amperayani S. Dengue viral infection in children: a perspective. Arch Dis Child 2012; 97:907-12.

2. Alexander N, Balmaseda A, Coelho IC, Dimaano E, Hien TT, Hung NT, et al. Multicentre prospective study on dengue classification in four South-east Asian and three Latin American countries. Trop Med Int Health 2011; 16:936-48.

3. World Health Organization. Dengue: guidelines for diagnosis, treatment, prevention and control. Geneva: World Health Organization; 2009.

4. Barniol J, Gaczkowski R, Barbato EV, Cunha RV, Salgado D, Martinez E, et al. Usefulness and applicability of the revised dengue case classification by disease: multi-centre study in 18 countries. BMC Infect Dis 2011; 11:106.

5. Lee LK, Thein TL, Kurukularatne C, Gan V, Lye DC, Leo YS. Dengue knowledge, attitudes, and practices among primary care physicians in Singapore. Ann Acad Med Singapore 2011; 40:533-8.

6. Fundacão Nacional de Saúde. Dengue: diagnóstico e manejo clínico. Brasília: Fundacão Nacional de Saúde; 2002.

7. Ministério da Saúde. Dengue: diagnóstico e manejo clínico: adulto e criança. Brasília: Ministério da Saúde; 2011.
8. Herdman M, Fox-Rushby J, Badia X. A model of equivalence in the cultural adaptation of HRQoL instruments: the universalist approach. Qual Life Res 1998; 7:323-35.

9. Reichenheim ME, Moraes CL. Operacionalização de adaptação transcultural de instrumentos de aferição usados em epidemiologia. Rev Saúde Pública 2007; 41:665-73.

10. Santos SL, Cabral AC, Augusto LG. Conhecimento, atitude e prática sobre dengue, seu vetor e ações de controle em uma comunidade urbana do Nordeste. Ciênc Saúde Coletiva 2011; 16:1319-30.

11. Naing C, Ren WY, Man CY, Fern KP, Qiqi C, Ning $\mathrm{CN}$, et al. Awareness of dengue and practice of dengue control among the semi-urban community: a cross sectional survey. J Community Health 2011; 36:1044-9.

12. Shuaib F, Todd D, Campbell-Stennett D, Ehiri J, Jolly PE. Knowledge, attitudes and practices regarding dengue infection in Westmoreland, Jamaica. West Indian Med J 2010; 59:139-46.

13. Kularatne SA. Survey on the management of dengue infection in Sri Lanka: opinions of physicians and pediatricians. Southeast Asian J Trop Med Public Health 2005; 36:1198-200.

Recebido em 18/Dez/2013

Versão final reapresentada em 23/Out/2014

Aprovado em 17/Nov/2014 